\title{
PENGGUNAAN MEDIA LECTORA INSPIRE X.6 UNTUK MENINGKATKAN HASIL BELAJAR AKUNTANSI SISWA SMK MA'ARIF 1
}

\section{THE USE OF LECTORA INSPIRE X.6 MEDIA TO DEVELOP THE RESULT OF LEARNING ACCOUNTANCY STUDENT IN SMK MA'ARIF 1}

\author{
Oleh: \\ Annisa Rahmawati \\ Prodi Pendidikan Akuntansi Universitas negeri Yogyakarta \\ nisooong@gmail.com \\ Isroah \\ Staf Pengajar Jurusan P. Akuntansi Universitas Negeri Yogyakarta
}

\begin{abstract}
Abstrak
Penelitian ini bertujuan untuk meningkatkan Hasil Belajar Akuntansi siswa kelas X AK 2 SMK Ma'Arif 1 Ngluwar Magelang Tahun Ajaran 2012/2013 menggunakan Media Lectora Inspire X.6. Penelitian ini merupakan penelitian tindakan kelas (Classroom Action Research) dengan subjek penelitian siswa kelas X AK 2 SMK Ma'Arif 1 Ngluwar, Magelang sebanyak 28 siswa yang terdiri dari dua siklus, setiap siklusnya memiliki empat langkah yaitu perencanaan, pelaksanaan, pengamatan, dan refleksi. Teknik pengumpulan data menggunakan observasi, tes, dan dokumentasi. Teknik analisis data yang digunakan adalah statistik deskriptif dengan persentase. Hasil penelitian menunjukkan bahwa Penggunaan Media Lectora Inspire X.6 dapat meningkatkan Hasil Belajar Akuntansi siswa kelas X AK 2 SMK Ma'Arif 1 Ngluwar Magelang tahun ajaran 2012/2013 yang dibuktikan dengan adanya peningkatan hasil belajar, pada siklus I, yaitu terjadi peningkatan sebesar $60,7 \%$ dari data pre test $17,86 \%$ dan post test $78,56 \%$. Peningkatan sebesar $64,29 \%$ juga terjadi pada siklus II dengan hasil pre test $28,57 \%$ dan post test $92,86 \%$. Dari data tersebut dapat diketahui bahwa hasil belajar meningkat sebesar $14,3 \%$ yang dihitung dari hasil belajar pada post test siklus I sebesar 78,56\% meningkat pada siklus II menjadi 92,86\%.
\end{abstract}

Kata kunci: Lectora Inspire X.6, Hasil belajar Akuntansi

\begin{abstract}
The aim of this research is to develop the Result of Learning Accountancy of the grade X AK 2 students in SMK Ma'arif 1 Nguwar Magelang During 2012/2013 by using Lectora Inspire X.6 Media.This research is a Classroom Action Research with 28 students of Grade X AK 2 in SMK Ma'arif 1 Ngluwar Magelang as the subject of the research. This research consists of two cycles where each of cycle has four steps includes planning, implementing, examining and reflecting. The data were collected by observation, test, and documentation. The analysis that was used is statistic-descriptive with percentages.From the analysis, it is found that the Use ofLectora Inspire X.6 Media could develop the Result of Learning Accountancy of the Grade X AK 2 SMK Ma'arif 1 Ngluwar Magelang during 2012/2013 that was proved with development of learning result, in the cycle I, there was $60.7 \%$ increasing $17.86 \%$ increasing from pre test and $78.56 \%$ from post test. There was also $64.29 \%$ increasing in the cycle II, with $28.57 \%$
\end{abstract}


increasing in pre test and $92.86 \%$ from post test. From the data, it is found that the learning result increased $14.3 \%$ which was counted from learning result in post test, $78.56 \%$ from the cycle I increased into $92.86 \%$ in the cycle II.

Keywords: Lectora Inspire X.6, Result of Learning

\section{A. PENDAhuluan}

Saat ini dalam dunia pendidikan, guru bukan hanya dituntut untuk profesional dalam mengajar, namun juga diharapkan mampu menguasai berbagai media pembelajaran. Pelaksanaan proses pembelajaran melibatkan beberapa komponen yang saling menunjang, antara lain tujuan, materi, guru, metode, media, siswa, lingkungan dan evaluasi (Sukardjo, 2010: 9). Masing-masing komponen tersebut membentuk sebuah sistem yang mendukung tercapainya tujuan bersama yakni siswa yang berhasil (output) dan lulusan yang berhasil (outcome). Dalam pelaksanaan pembelajaran dituntut adanya dukungan guru dan penggunaan media pembelajaran yang digunakan.

Media pembelajaran merupakan salah satu komponen pembelajaran yang mempunyai peranan penting dalam kegiatan belajar mengajar. Media pembelajaran didefinisikan sebagai alat, metode, dan teknik yang digunakan di dalam kelas maupun di luar kelas (Supriyadi, 2007: 61). Salah satu jenis media pembelajaran yang dapat digunakan dalam proses pembelajaran adalah media audio visual. Media ini dapat digunakan sebagai penyampaian fakta awal yang lengkap dan dapat pula dipakai sebagai penguatan (Supriyadi, 2007:62).

Penguasan media pembelajaran bagi seorang guru sangatlah penting, karena dengan adanya media pembelajaran guru dapat memberikan variasi proses pembelajaran. Keberhasilan guru dalam mengajar dapat dilihat melalui hasil belajar siswa. Sistem pendidikan nasional yang didalamnya terdapat rumusan tujuan pendidikan, baik tujuan kurikuler maupun tujuan instruksional menggunakan klasifikasi hasil belajar. Hasil belajar siswa adalah kemampuan-kemampuan yang dimiliki siswa setelah ia menerima pengalaman belajarnya (Nana Sudjana, 2002: 22). Dari hasil observasi yang di lakukan peneliti terhadap siswa kelas $X$ Akuntansi 2 SMK Ma'Arif 1 Ngluwar, diketahui bahwa hasil belajar rendah. Hal itu ditandai dengan hampir sebagian besar siswa tidak mencapai nilai Kriteria Ketuntasan Minimal (KKM) Akuntansi yaitu sebesar 75 .

Berdasarkan latar belakang diatas, maka peneliti tertarik untuk melakukan penelitian dengan judul "Penggunaan Media Lectora Inspire X.6 untuk Meningkatkan Hasil Belajar Akuntansi Siswa Kelas X AK 2 SMK Ma’Arif 1 Ngluwar, Magelang Tahun Ajaran 2012/2013”. 


\section{B. METODE PENELITIAN}

\section{Jenis Penelitian}

Jenis Penelitian yang digunakan adalah penelitian tindakan kelas (Classroom Action Research). Penelitian yang dilaksanakan adalah Penelitian Tindakan Kelas (PTK). Menurut Suharsimi Arikunto (2009: 3), PTK merupakan suatu pencermatan terhadap kegiatan belajar yang berupa suatu tindakan, yang sengaja dimunculkan dan terjadi dalam kelas bersama.

\section{Waktu dan Tempat Penelitian}

Penelitian ini akan dilaksanakan di SMK Ma'Arif 1 Ngluwar, Magelang yang beralamatkan di Jl. KR. Syahid, Mambang, Ngluwar, Magelang. Waktu penelitian adalah April-Mei 2013 dengan mengikuti jadwal pelajaran yang ada di sekolah.

\section{Subjek dan Objek Penelitian}

Subjek dalam penelitian ini adalah siswa kelas $X$ AK 2 SMK Ma'Arif 1 Ngluwar, Magelang yang berjumlah 28 siswa. Sedangkan objek penelitian ini adalah peningkatan hasil belajar Akuntansi siswa kelas X AK 2 SMK Ma'Arif 1 Ngluwar, Magelang melalui pembelajaran dengan media Lectora Inspire X.6.

\section{Teknik Pengumpulan Data}

\section{a. Observasi}

Observasi yang akan dilakukan merupakan jenis observasi partisipatif. Observasi partisipatif adalah observasi yang dilakukan apabila observer ikut serta dalam kegiatan atau situasi yang dilakukan oleh observant (Wina Sanjaya, 2010: 92). Peneliti melakukan tindakan pengamatan terhadap proses pembelajaran yang kemudian direkam dalam catatan lapangan. Tujuan diadakannya observasi yaitu untuk mengetahui kegiatan siswa dalam proses pembelajaran selama penelitian berlangsung.

\section{b. Tes}

Tes adalah digunakan untuk mengukur dan menilai hasil belajar kognitif berkenaan dengan penguasaan bahan pengajaran dengan tujuan pendidikan dan pengajaran (Masnur Muslich, 2007: 117). Tes yang dipakai oleh peneliti adalah pre test dan post test untuk mengukur hasil belajar siswa. 


\section{c. Dokumentasi}

Dokumentasi dilakukan dengan mencari data berupa catatan maupun dokumen tertulis lainnya (Suharsimi Arikunto, 2002: 206). Dokumentasi juga berupa data Rencana Pelaksanaan Pembelajaran (RPP), silabus, catatan lapangan, hasil pre test dan post test serta foto selama kegiatan penelitian di sekolah.

\section{Intrumen Penelitian}

a. Tes

Tes adalah alat yang digunakan untuk mengetahui kemampuan siswa dalam mempelajari akuntansi. Dalam penelitian ini digunakan dua macam tes, yaitu pre test yang diberikan pada pra tindakan dan post test pada pasca tindakan siklus I dan siklus II. Tes yang digunakan dalam penelitian ini dalam bentuk essay dengan materi neraca saldo dan jurnal penyesuaian.

\section{b. Penilaian Media Lectora Inspire X.6}

Dalam penelitian ini, peneliti menggunakan software lectora inspire X.6. Untuk mengetahui kelayakan media ini dalam penelitian maka diperlukan evaluasi untuk menilai kelayakan media lectora inspire X.6.

\section{c. Catatan Lapangan}

Catatan lapangan digunakan untuk mencatat kegiatan yang dilakukan selama penelitian berlangsung. Catatan tersebut mencakup hal-hal yang terjadi di kelas ketika tindakan penelitian dilaksanakan.

\section{Prosedur Peneitian}

Penelitian ini merupakan penelitian tindakan kelas dan pengembangan media, karena dalam penelitian ini peneliti juga mengembangkan software lectora inspire X.6 yang digunakan sebagai media dalam penelitian. Langkah-langkah pengembangan yang dilakukan dalam penelitian ini sebagai berikut :

1. Potensi dan Masalah

Peneliti mencari tahu penyebab rendahnya nilai belajar siswa di SMK Ma'Arif 1 Ngluwar dan kemudian menetapkan suatu desain pembelajaran yang aktif dan menarik bagi siswa yaitu dengan menggunakan software lectora inspire X.6

2. Pengumpulan Data

Dalam hal ini pengumpulan data yang dilakukan peneliti adalah membuat modul materi pembelajaran yang akan dilakukan oleh peneliti. 
3. Validasi Desain

Seperti halnya penelitian Research and Development (R\&D), peneliti juga me

lakukan validasi terhadap desain dan produk yang telah dibuat oleh peneliti untuk mengetahui kelayakan produk tersesbut.

4. Uji Coba Produk dan Produksi Masal

Dalam penelitian ini peneliti tidak melakukan tahap uji coba, melainkan langsung memproduksi masal dan menggunakannya di lapangan. Setelah peneliti mendapat validasi kelayakan produk dari ahli media, segera dilakukan tindakan penelitian selanjutnya oleh peneliti yaitu penelitian tindakan kelas dengan penggunaan media lectora inspire X.6 di dalamnya.

Tahapan penelitian selanjutnya adalah penelitian tindakan kelas. Penelitian ini dilakukan dalam dua siklus, dimana dalam dua siklus. Adapun langkah-langkah pelaksanaan penelitian tindakan ini setiap siklusnnya adalah sebagai berikut:

a. Rencana Tindakan

Menyusun Rencana Pelaksanaan Pembelajaran (RPP) tentang materi yang akan diajarkan dengan menggunakan media pembelajaran Lectora Inspire X.6.

1) Menyiapkan skenario pembelajaran untuk pelaksanaan tindakan dengan menggunakan media pembelajaran Lectora Inspire X.6.

2) Mempersiapkan soal pre test untuk siswa.

3) Mempersiapkan sarana dan media pembelajaran yang dibutuhkan dalam proses pembelajaran.

4) Mempersiapkan soal post test untuk siswa yaitu tes yang akan diberikan pada akhir siklus. Soal tes disusun oleh peneliti dengan pertimbangan guru yang bersangkutan.

b. Pelaksanaan Tindakan

Dalam penelitian ini, tahap tindakan berupa dilaksanakannya pembelajaran Akuntansi dengan menggunakan media pembelajaran Lectora Inspire X.6. Sebelum penelitian dilakukan guru memberikan soal pretest kepada seluruh siswa, untuk mengetahui hasil yang diperoleh siswa sebelum menggunakan media pembelajaran. Selanjutnya guru menyampaikan materi pembelajaran dengan menggunakan media pembelajaran Lectora Inspire X.6. Setelah presentasi selesai disampaikan, guru memberikan soal post test dengan maksud untuk mengetahui hasil yang diperoleh siswa setelah mendapat penjelasan materi dengan menggunakan media pembelajaran. 
c. Observasi terhadap siswa

Selama proses pembelajaran berlangsung peneliti beserta guru mengamati jalannya proses pembelajaran untuk mengetahui sejauh mana siswa terlibat dalam kegiatan pembelajaran. Penelitian ini bersifat kolaborasi, sehingga dalam tahap observasi pengamatan dilakukan oleh peneliti dibantu oleh guru dan rekan sejawat.

d. Evaluasi dan Refleksi

1) Evaluasi

Pada tahap pelaksanaan ini, evaluasi berdasarkan standar minimal untuk mengetahui keberhasilan pembelajaran dilihat dari segi hasil yaitu hasil belajar mata pelajaran akuntansi yang berupa nilai angka sesudah dilakukan tindakan.

2) Refleksi

Proses refleksi dilakukan dengan diskusi bersama guru mata pelajaran mengenai catatan lapangan yang dibuat selama proses pembelajaran. Berdasarkan catatan lapangan tersebut, dilakukan evaluasi terhadap pelaksanaan pembelajaran, kemudian dilakukan identifikasi permasalahan yang muncul selama proses pembelajaran, selanjutnya menyusun rancangan perbaikan pada siklus II, untuk mencapai hasil yang optimal.

\section{Teknik Analisis Data}

a. Analisis Data Kuantitatif

Analisis data kuantitatif dilakukan dengan melakukan analisis hasil belajar ranah kognitif untuk mengetahui ketuntasan nilai yang didapat pada setiap akhir siklus dan menghitung banyaknya (persentase) siswa yang tuntas belajar. Dalam menganalisis hasil belajar siswa digunakan rumus :

$$
P=\frac{F}{N} \times 100 \%
$$

Keterangan :

$\mathrm{F}=$ Jumlah siswa yang memperoleh nilai $\geq 75$

$\mathrm{N}=$ Jumlah siswa (maksimal) yang mengikuti tes

$\mathrm{P}=$ Persentase siswa yang tuntas

(Dimodifikasi dari Djamarah, 2010: 264)

b. Analisis Data Kualitatif

Teknik analisis mengacu pada metode analisis dari Miles Huberman (Sugiyono, 2009: 246-252) yang dilakukan dalam tiga komponen berurutan, yaitu: reduksi data, penyajian data,dan penarikan kesimpulan. 


\section{Indikator Keberhasilan}

Menurut Mulyasa (2008: 101) "Dilihat dari segi proses, pembelajaran berhasil dan berkualitas jika seluruhnya atau setidak-tidaknya sebagian besar $(75 \%)$ peserta didik terlibat secara aktif, baik fisik, mental maupun sosial dalam pembelajaran". Dalam penelitian ini indikator keberhasilan yang digunakan adalah sekurang-kurangnya $75 \%$ siswa memperoleh nilai hasil belajar minimal 75 .

\section{HASIL PENELITIAN DAN PEMBAHASAN}

Berdasarkan pelaksanaan pembelajaran dengan media lectora inspire X.6peningkatan Hasil Belajar Akuntansi dapat dilihat dari analisis hasil belajar yang diukur dari hasil post test siklus I dan siklus II. Siswa dikatakan tuntas apabila telah memperoleh nilai 75 atau lebih dari hasil post test di tiap siklusnya. Berikut ini data peningkatan ketuntasan belajar pada siklus I dan siklus II:

Tabel 8. Perbandingan Ketuntasan Belajar Siklus I dan Siklus II

\begin{tabular}{|c|c|c|c|}
\hline \multirow{2}{*}{ Nilai } & \multicolumn{2}{|c|}{ Hasil Post Test } & \multirow{2}{*}{ Peningkatan } \\
\hline & Siklus I & Siklus II & \\
\hline Nilai $\geq 75$ & $\begin{array}{l}78,56 \% \text { atau } \\
22 \text { dari } 28 \\
\text { siswa }\end{array}$ & $\begin{array}{l}92,86 \% \text { atau } 26 \text { dari } \\
28 \text { siswa }\end{array}$ & $14,3 \%$ \\
\hline Nilai $<75$ & $\begin{array}{l}21,44 \% \text { atau } 6 \\
\text { dari } 28 \text { siswa }\end{array}$ & $\begin{array}{l}7,14 \% \text { atau } 2 \text { dari } 28 \\
\text { siswa }\end{array}$ & $-14,3 \%$ \\
\hline
\end{tabular}

Dari tabel diatas dapat diketahui Hasil Belajar Akuntansi pada siklus I terjadi peningkatan60,7\% pada mata pelajaran akuntansi kompetensi dasar menyusun kertas kerja. Jumlah siswa yang telah mencapai KKM pada akhir siklus I sebanyak 22 siswa atau 78,56\%. Berdasarkan hasil dari nilai pre test dan post test dapat dilihat adanya peningkatan hasil belajar setiap siswa.

Peningkatan sebesar 64,29\% juga terjadi pada siklus II mata pelajaran akuntansi kompetensi dasar menyusun laporan keuangan.Demikian juga pada peningkatan hasil belajar secara individual, semua siswa mengalami kenaikan hasil belajar yang dilihat dari hasil pre test dan post test di siklus II. Jumlah siswa yang telah mencapai KKM pada akhir siklus II sebanyak 26 siswa dari 28 siswa atau $92,86 \%$.

Dari penjelasan diatas, dapat diambil kesimpulan bahwa terjadi peningkatan Hasil Belajar Akuntansi dari siklus I ke siklus II. Sebesar 14,3\% Hasil Belajar Akuntansi Standar Kompetensi Menyusun Laporan Keuangan dari ketuntasan belajar padasiklus I sebesar 78,56\% ke siklus II sebesar $92,86 \%$. Dari data tersebut dapat diketahui bahwa pada setiap siklus baik siklus I maupun siklus II sebanyak lebih dari 75\% siswa telah mencapai 
ketuntasan minimal belajar standar kompetensi menyusun laporan keuangan, yaitu 75 .

\section{SIMPULAN}

Berdasarkan hasil penelitian dan pembahasan pada bab IV disimpulkan bahwa Penggunaan Media Lectora Inspire X.6 dapat meningkatkan Hasil Belajar Akuntansi siswa kelas X AK 2 SMK Ma'Arif 1 Ngluwar Magelang tahun ajaran 2012/2013 yang dibuktikan dengan adanya peningkatan hasil belajar, pada siklus I, yaitu terjadi peningkatan sebesar 60,7\% dari data pre test $17,86 \%$ dan post test $78,56 \%$. Peningkatan sebesar $64,29 \%$ juga terjadi pada siklus II dengan hasil pre test $28,57 \%$ dan post test $92,86 \%$. Dari data tersebut dapat diketahui bahwa hasil belajar meningkat sebesar $14,3 \%$ yang dihitung dari hasil belajar pada post test siklus I sebesar $78,56 \%$ dan meningkat pada siklus II menjadi 92,86\%.

\section{E. DAFTAR PUSTAKA}

Masnur Muslich. (2007). Kurikulum Tingkat Satuan Pendidikan (KTSP). Jakarta: Bumi Aksara

Mulyasa. (2008). Kurikulum Berbasis Kompetensi. Bandung: Remaja Rosdakarya.

Nana Sudjana. (2002). Penilaian Hasil Proses Belajar Mengajar. Bandung: Remaja Rosdakarya.

Sugiyono. (2009). Metode Penelitian Kuantitatif Kualitatif dan RnD. Bandug: Alfabeta.

Suharsimi Arikunto. (2002). Metodologi Penelitian Pendidikan. Jakarta: Rineka Cipta. . (2009). Penilaian Tindakan Kelas. Jakarta: Bumi Aksara.

Sukardjo. (2010). Pendidikan Konsep dan Aplikasinya. Jakarta: Rajawali Pers.

Supriyadi. (2007). Jembatan. Yogyakarta: Beta Offset. . (2010). Strategi Belajar Mengajar. Jakarta: Rineka Cipta.

Wina Sanjaya. (2010). Strategi Pembelajaran Berorientasi Standar Proses Pendidikan. Jakarta: Kencana Prenada Media Group. 